Makale türü / Article type: Araştırma / Research

\title{
Kariyer Değerlerinin Tükenmişlik Düzeyi Üzerindeki Etkisi: Hopa İlçesinde Öğretmenler Üzerinde Bir Uygulama
}

$* * *$

\section{The Effect of Career Anchors on Burnout Level: An Application on Teachers in Hopa ${ }^{1}$}

\author{
Dr. Öğr. Üyesi Özgür Doğan \\ Artvin Çoruh Üniversitesi, Hopa İIBF, ozgurdgn@artvin.edu.tr \\ (ORCID: 0000-0003-1573-4042) \\ Arş. Gör. Muhammed Kürşad Dursun \\ Artvin Çoruh Üniversitesi, Hopa İIBF, kursadursun@artvin.edu.tr \\ (ORCID: 0000-0001-6169-5158) \\ Özet
}

\begin{abstract}
Tükenmişlik sendromu günümüz iş dünyasının önemli bir sorunudur. Tükenmişliği doğuran birçok içsel ve dışsal neden vardır. Bireylerin, mesleki değerleriyle uyumlu bir mesleği seçmemeleri ise tükenmişliği doğuran ya da düzeyini arttıran önemli bir içsel faktördür. Bu çalışmanın temel amacı, öğretmenlerin kariyer değerlerinin, tükenmişlik düzeyleri üzerindeki etkisini incelemektir. $\mathrm{Bu}$ bağlamda, kariyer değerleri ve tükenmişlik konularıyla ile ilgili literatür incelenmiştir. Aralarındaki ilişki, Hopa ilçesinde görev yapan öğretmenlerin oluşturduğu 154 kişilik bir örneklem üzerinde araştırılmıştır. Sonuç olarak, güvenlik değerinin duygusal tükenme ile pozitif yönlü, yaşam tarzı değerinin ise negatif yönlü bir ilişkiye sahip olduğu bulgusuna ulaşılmıştır. Yaşam tarzı değerinin ise azalan kişisel başarı boyutuyla negatif yönlü bir ilişkiye sahip olduğu bulgusuna ulaşılmıştır. Yapılan regresyon analizi; güvenlik ve yaşam tarzı değerlenin, bazı tükenmişlik boyutları üzerinde etkileme gücüne sahip olduğunu göstermiştir.
\end{abstract}

Anahtar Kelimeler: Tükenmişlik, Kariyer, Kariyer Değerleri, Jel Sınıflandırması: M10, M19

\section{Abstract}

\footnotetext{
${ }^{1}$ Bu çalışma 8-10 Nisan tarihleri arasında düzenlenen 1st International Congress on Vocational and Technical Sciences (UMTEB-I) / April 8-10, 2017, Batumi/GEORGIA kongresinde bildiri olarak sunulmuş ve kongre kitapçığında özet bildiği olarak yayımlanmıştır.
} 
Burnout syndrome is a major problem is today's business world. There are many internal and external causes which is born burnout. People do not select occupation which is appropriate for occupational values so that this is the most important internal factor of being born burnout or increasing of level of burnout. The main aim of this study is to analyse which career anchors of teachers effect on their burnout levels. In this context, literature about career anchors and burnout level were examined. The relationship between them was investigated on 154 teachers who were working in Hopa. As a result, it was attained the findings that the security anchor have a positive relationship with the emotional exhaustion and the lifestyle anchor have a negative relationship with the emotional exhaustion. Also, it is attained the finding that the lifestyle of career anchor have a negative relationship with the personal accomplishment. Regression analysis showed that the security anchor and the lifestyle anchor have a power of influence on some burnout dimensions.

Keywords: Burnout, Career, Career Anchors,

JEL Classification: M10, M19

\section{GIRISŞ}

Günümüzde, bireyler her zamankinden daha fazla bir biçimde, kendilerini meslekleri hatta daha geniş bir kavram olan kariyerleri ile ifade etmektedirler. Yaşamın her alanında, kaçınılmaz biçimde yaşanan değişim, bireylerin kariyerlerini de etkilemektedir. Çoğunlukla, istikrarlı bir ortama sahip olma tercihini kullanan insanoğlu için, bu değişimlere adapte olmak, sürekli tetikte olmayı da zorunlu kılmaktadır.

Bireylerin, mesleki bir alanda ve bir örgüt içerisinde verdikleri mücadele, gerek meslek, örgüt, gerekse kendileri dışında kalan birçok dışsal boyutla da ilişkilidir. Ancak en az bu dişsal boyutlar kadar önemli olan diğer bir boyut da bireylerin meslekleriyle ne ölçüde uyumlu olduklarıdır. Bu uyumun en önemli göstergesi ise, bireylerin sahip oldukları kariyer değerlerinin, mesleki değerlerle ne ölçüde uyuştuğudur. Muhtemel bir uyum eksikliği, örgütsel ve bireysel açıdan birçok olumsuzluğa neden olması açısından önemlidir. Tükenmişlik kavramı da bu bağlamda ele alınması gereken önemli bir sorunu ifade etmektedir.

\section{KAVRAMSAL ÇERÇEVE}




\subsection{Kariyer Değerleri}

Kariyer kavram1, Latince "Carrus" kelimesinden gelmektedir ve kelime anlamı itibariyle, at arabalarının kazanmak için mücadele ettikleri bir yarışı ve yarış alanını yani "hipodromu" ifade etmektedir. Günümüzde ise kariyer kavramı; bir işi, iş unvanını, mesleği vb. açıklamak için kullanılan, latince anlamından farklılaşan ve çalışma hayatının dinamizminden kaynaklanan bir biçimde, tanımlama güçlüğü çekilen bir kavram halini almaktadır (Ross, Beggs ve Young, 2011, s. 15).

Kariyer kavramına ilişkin literatür incelendiğinde dört ayrı anlamda kariyer kavramının kullanıldığı görülmektedir. Birinci anlamıyla kariyer, bir bireyin çalışma yaşamı boyunca, işle ilgili bir biçimde, hiyerarşik olarak yukarıya doğru ilerlemesini ifade etmektedir. İkinci anlamıyla kariyer, toplumca kabul gören ve değer verilen bir mesleğe (öğretmen, hâkim, doktor v.b.) sahip olmayı ifade etmektedir. Üçüncü anlamıyla kariyer, bireyin, yaşamı boyunca pozisyon ya da sektör açısından birbirinden farklılık gösteren birçok mesleği yerine getirdiği, her bir mesleğe ilişkin farklı bir deneyim ve içsel tatmin duygusu yaşadığı işleri yapmasını, ifade etmektedir. Dördüncü anlamıyla kariyer ise, bireyin çalışma hayatı boyunca, mesleğini ya da sektörünü değiştirse bile, gelişimini ve doyum elde etmesini sağlayan, ardışık bir roller dizisine sahip olmasını ifade etmektedir (Hall, 2002, s 8-10).

Günümüzde kullanılan kariyer geliştirme kavramı önceleri; "mesleki rehberlik (vocational guidance)" olarak ifade edilmekteydi. Meslek (vocation) kelimesinin kökeni ise, "çağırmak" anlamına gelen, Latince "vocare" kelimesine dayanmaktadır. Bir meslek, bu nedenle, "tanrının bir daveti ya da çağrısı", olarak kabul edilmekteydi. Birçok insan bugün, muhtemelen bilinçsiz bir biçimde, sahip oldukları işlerinden meslek kelimesinin eski anlamıyla, yani bir daveti kabul etmek biçiminde bahsetmektedirler. Onları, bu daveti kabul etmeye iten en önemli şey ise, doğuştan gelen bazı yeteneklerinin farkında olmaları ya da bu davete icabet etmenin bir provasını yapma (iş deneyimlerine sahip olma) şansına sahip olmaları, biçiminde ifade edilebilir (Goodman, 2011, s. 87). 
Bireyler, ister kendiliğinden, isterlerse çeşitli iş deneyimleri sonucunda bir mesleği icra etmeye başlamış olsunlar, mesleki yaşama dair birtakım hususların kendileri için daha önemli olduğunu zamanla fark etmektedirler. Kariyer değerleri olarak da ifade edilen bu unsurlar temelde üç bileşene sahiptir. Bunları ise aşağıdaki gibi vermek mümkündür (Schein, 2006, s. 3):

- Bireyin, farklı iş ortamlarındaki başarıları sonucunda, kendisinin algıladığı doğal yetenekler ve beceriler,

- Bireyin, çalışma yaşamı içerisinde, kendini tanıma ve geri bildirim alma yoluyla fark ettiği ihtiyaç ve güdüler,

- Bireyin, çalışma yaşamındaki deneyimleri yoluyla, algıladığı, çalışma yaşamıyla ilişkili (mesleki, örgütsel, çalışma arkadaşları v.b.) değerler.

Schein, bireylerin çalışma yaşamında sahip olduğunu düşündüğü kariyer değerlerini, aşağıdaki gibi sekiz başlık altında ele almaktadır (Schein, 1990a, s. 259).

Teknik ya da fonksiyonel beceri (TF): Bireyin, kendisini üstün hissettiği, hoşlandığı ve en önemli boyutu olarak daha zorlayıcı olmasını ifade ettiği, özel bir iş ya da beceri alanında faaliyet göstererek, kabul görmek istemesini ifade etmektedir.

Genel yönetim becerileri (GYB): Bu değer, bireyin, kararlarının gerçekten fark yaratacağını düşündüğü; sahip olduğu analitik, iletişimsel ve duygusal becerileri üst düzeyde kullanacağ 1 , yüksek sorumluluk gerektiren üst düzey bir pozisyonu arzulamasını ifade etmektedir.

Otonomi/Özerklik (O/Ö): $\mathrm{Bu}$ değer, örgütsel kurallar ve sınırlamalardan bağımsız bir biçimde, bireyin işiyle ilgili kendi kararlarını alabildiği bir durumda bulunmasını ifade eder.

Güvenlik (GÜV): Bu değer bireylerin ekonomik açıdan ve iş güvenliği açısından kendini güvende hissetmesini ifade etmektedir.

Girişimci yaratıcılık (GY): $\mathrm{Bu}$ değer bireyin, yaratıcılığg ile ilişkilendirilen bir ürün ya da hizmet yaratmasını ve böylelikle çalıştı̆̆ örgütte kendisine ait bir şeyler görebilmesini, ifade etmektedir. 
Hizmet/bir amaca bağlanmışlık (HAB): Bu değer bireyin, dünyayı daha iyi bir yer haline getirmek, insanlara yardım etmek ve olumsuzlukları ortadan kaldırmak v.b. gibi davranışlar sergilemesine izin veren bir kariyere sahip olmasını ifade etmektedir.

Saf meydan okuma (SMO): Bu değer, imkânsız gibi görünen engellerle, olasılıklarla ya da örgüt içerisindeki diğer bireylerle, rekabetçi ve zorlayıcı bir ortamda mücadele etmekten hoşlanmayı ifade etmektedir. Hatta, kariyerin temel belirleyicisinin, mücadeleye ve rekabete açık iş ve örgüt ortamı içerisinde olmak, şeklinde ifade edildiği bir değeri yansıtmaktadır.

Yaşam tarzı (YT): Çalışan eşlerin artması ve toplumda, yaşamın diğer boyutlarına göre, işin önemine verilen değerin değişmesiyle birlikte; daha artan sayıda birey kariyerini yaşam tarzıyla uyumlu hale getirmeye, işlerini seçerken kişisel ve ailevi ihtiyaçları birlikte göz önünde bulundurmaya çalışmaktadır. Bu değer, kişisel ve ailevi ihtiyaçların birlikte göz önünde bulundurularak bir kariyer seçimi yapılmasını ve kariyerin sürdürülmesini ifade etmektedir.

Çağımızda örgütler için kariyer olgusunun yönetilmesini güçleştiren, çalışan profiliyle ilgili bir takım önemli değişimler mevcuttur. Bu değişimler, örgütlerin kariyer yönetimine bakışını etkilediği kadar, bireylerin, sahip oldukları kariyer değerlerini gözden geçirmelerine de neden olmaktadır. Bu değişimleri aşağıdaki gibi ifade etmek mümkündür (Greenhaus, Callanan, Godshalk, 2010, s. 14-15);

-Yüksek beklentilere sahip olan ve beklentileri gerçekleşmediğinde, daha çabuk bir biçimde, öfke, hayal kırıklığı ve doyumsuzluk duygusu yaşayan bir işgücünün varlığı,

-Çalışma yaşamında özgürlüğe, özerkliğe ve karar verme yetkisine sahip bir biçimde, yüksek performans gösterebileceği bir iş ortaya koymay1 terfi etmekten daha fazla önemseyen bir işgücünün varlı̆̆g,

- Cinsiyete dayalı iş ya da iş rolleri ayrımının giderek daha fazla ortadan kalkması ve bu durumun gerek örgüt gerekse birey açısından, kariyer olgusuna bakışı farklılaştırması, 
-Anlamlı ve zorlayıcı bir iş arayışının, kişisel yaşam tarzı ile bütünleştirilmeye çalışılması (çalışan eşler sorunu, iş-aile dengesini sağlama v.b.) ve kariyer konusuna bakışın, bir mesleğe ya da işe bakışın çok ötesine geçmesi,

- Bireylerin kariyer yönelimlerinin ve kariyer değerlerinin (iş güvenliği, özgürlük/özerklik, iş-aile dengesi sağlama v.b.) benzer olmaması.

Çalışan profiliyle ilgili olarak bahsedilen ve giderek yaygın biçimde kabul gören bu değişimler, aslında bireylerin kariyeriyle ilgili birtakım sorunlarının ortaya çıkmasını sağlayacak olumsuzlukları da içermektedir. Yapılan araştırmalar, "kariyer tükenmişliği" kavramı ile ifade edilen, daha çok, idealist ve yüksek derecede motive olmuş bireylerin yaşadığı bir tükenmişliğin, önemli olduğuna işaret etmektedir. İdealist bireyler, çalışma hayatlarının, daha kapsamlı bir yapı olarak yaşamlarına dair bir mesele olduğunu ve bir işi yapmanın kendi varlıklarına anlam katan bir şey olduğunu düşünmektedirler. Kendilerini işleriyle tanımladıklarından, bu durum onlar için yeterince motive edicidir. $\mathrm{Bu}$ motivasyon unsurları ise temel olarak; evrensel beklentiler (en önemli şeyin herkes için anlamlı bir şey yapmak olması), mesleğe özel beklentiler (mesleğini eksiksiz yaparak katkı sunmak), kişisel beklentiler (önemli bir insanın ya da olayın ilham kaynağı olduğu, içselleştirilmiş bir duyguyla, işini eşleştirmesi) şeklinde ifade edilmektedir (Pines, 1996, s. 83). Pines kariyer tükenmişliğini bir model olarak şekil l'deki gibi ifade etmektedir.

Bireylerin iş dünyasında elde edeceği çıktılar, bireyler ve onların algıladığı çevre arasındaki etkileşimin bir sonucudur. Destekleyici bir çevrede, yüksek derecede motivasyona sahip çalışanlar üstün bir performansa sahip olabileceklerdir.

Üstün bir performans ise, beklentilerini ve motivasyonlarını arttıracak olan, anlamlı gelme ve başarılı olma duygularını arttıracaktır. Stresli bir çevrede ise tükenmişlik kaçınılmaz olacaktır. Motive olmuş insanların egoları performanslarına bağlıdır ve hayal kırıklığı ise, en güçlü tükenmişlik nedenidir (Pines, 1996, s. 85). 
Kariyer tükenmişliği ile ilgili yapılan çalışmalar kariyer tükenmişliğini, bireyin çalışma yoluyla hayatına bir anlam katma çabasının başarısızlıkla sonuçlanması şeklinde ifade etmektedir. Üstelik çalışma yoluyla hayatına anlam katmaya çalışan bireylerin, bilinçsiz bir biçimde, yardım almaksızın, mesleki değerlerini sorgulamaksızın yaptıkları meslek tercihleri, tükenmişliğe -daha özel bir biçimi olarak ise kariyer tükenmişliğine- yol açmaktadır (Goodman, 2011, s. 87-88).

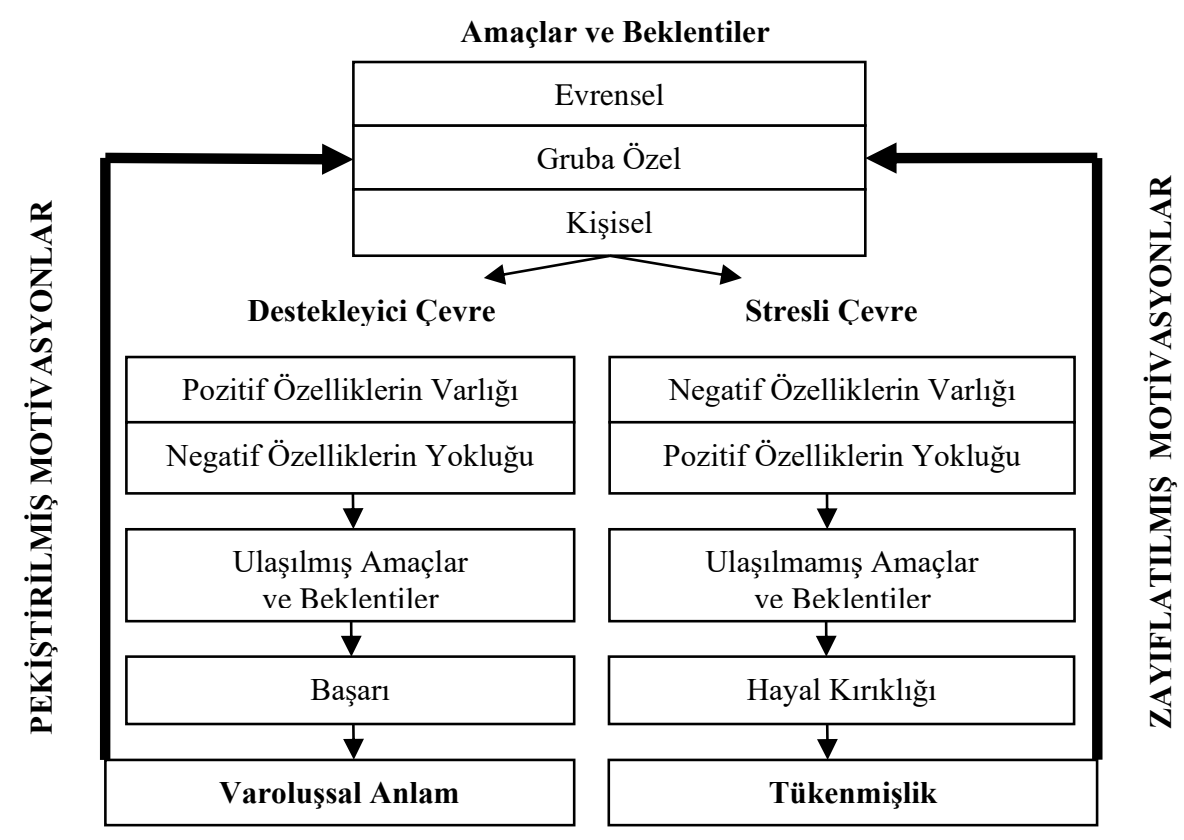

Şekil 1: Kariyer tükenmişlik modeli

Tükenmişlik konusunun, literatürde işle ilişkili değişkenlere dayanılarak açıklanmaya çalışılması, bir bakış farklılığına işaret etmektedir. $\mathrm{Bu}$ durumun temelinde ise tükenmişliği açıklama gücü olan öncüllerin örgütsel değişkenler olduğu varsayımı yatmaktadır. Ancak kişisel değişkenlerin öncüllüğü de en az örgütsel değişkenler kadar önem arz etmektedir (Pines, 2002, s. 121).

\subsection{Tükenmişlik}


Tükenmişlik kavramı ilk kez 1974 yılında H.J. Freudenberger tarafından; "Başarısız olma, yıpranma ya da yoğun ilgi duyulan; enerji, güç ve kaynaklara sahip olamamanın beraberinde getirdiği tükenme hissi" şeklinde ifade edilmiştir (Freudenberger, 1974, s. 159).

Cherniss tükenmişliği; "çalışanların, işle ilgili sahip oldukları gerginliklere bir cevap olarak, tutum ve davranışlarının olumsuz bir biçime dönüştüğü bir süreç" olarak ifade etmektedir (Cherniss, 1980, s. 5). Edelwich ve Brodsky ise tükenmişliği; "İnsanlara yardım sağlayan mesleklere sahip bireylerin, işlerinde sahip oldukları koşulların bir sonucu olarak, idealizm, enerji ve amaçlarının, artan bir biçimde azalması" şeklinde ifade etmektedir (Wasık ve Bryant, 2001: 216).

Pines ve Aronson ise tükenmişliği; "Uzun bir süre, çeşitli durumlar içerisinde, duygusal olarak talep eder bir biçimde bulunmaktan kaynaklanan, fiziksel, duygusal ve zihinsel tükenmişlik" şeklinde ifade etmektedir (Pines ve Aronson, 1988, s. 9).

Hallsten ise tükenmişliği; "ortaya çıkması için gerekli bir nedenin (durumun) var olduğu, bir yıpranma sürecinden kaynaklanan, bir çeşit depresyon" şeklinde tanımlamaktadır (Hallsten, 1993, s. 99).

Tükenmişliği bir süreç olarak ve alt boyutlara sahip bir kavram olarak ifade eden çalışmalar da mevcuttur.

Örneğin Jones ve Emanuel tükenmişliği, 1sınma, kaynama ve patlama şeklinde, daha çok kimyasal bir süreci temsil eden 3 aşamalı bir süreç ile ifade etmektedirler (Jones ve Emanuel'den aktaran Edmonson ve Thompson, 2002, s.162). Benzer bir biçimde Spaniol ise tükenmişliği, fiziksel kavramlarla ifade ederek; birinci derece tükenmişlik (kısa sürelerle ortaya çıkan, yorgun olma, huysuz olma, kaygılı olma ve kararsız/karışık duygulara sahip olma durumu), ikinci derece tükenmişlik (benzer duyguların uzun süreli olması durumu), üçüncü derece tükenmişlik (baş ağrısı, ülser ve sırt ağrısı gibi, fiziksel hastalık belirtilerinin meydana çıkması) şeklinde 3 aşamayla açıklamaktadır (Jones ve Emanuel'den aktaran Edmonson ve Thompson, 2002, s. 163). 
Edelwich ve Brodsky ise tükenmişliğin; idealist heves, durgunluk, hayal kırıklığı ve duyarsızlık olarak ifade edilen 4 dönemi içeren bir süreç olduğunu ifade etmektedirler (Edelwich ve Brodskyden aktaran Wasık ve Bryant, 2001, s. 217).

Tükenmişliği alt boyutlara sahip bir kavram olarak ifade eden araştırmacılarda mevcuttur. Örneğin Maslach, 3 boyuta sahip bir tükenmişlik modeli geliştirmiştir. Maslach'ın modeline göre tükenmişlik; bireyin, işle ilgili olarak kronik hale gelmiş, duygusal ve kişilerarası stres kaynaklarına karşı gecikmiş bir tür tepkisi olarak ifade edilmektedir. Karmaşık sosyal ilişkilerle bağlantılı bir biçimde yaşanan ve bireyin hem kendisini hem de diğer bireyleri algılamasına bağlı biçimde gelişen, bireysel bir stres tecrübesidir. Maslach'a göre tükenmişlik; "duygusal tükenme, duyarsızlaşma ve azalan kişisel başarıyı içeren, psikolojik bir hastalık belirtisi" şeklinde tanımlanmaktadır (Maslach ve Goldberg, 1998, s.64). Ayrıca Maslach tükenmişliğin genellikle, insanlarla yoğun bir biçimde ilişkide bulunmayı gerektiren işlere sahip bireylerde, ortaya çıktığını ifade etmektedir (Maslach ve Jackson, 1981, s. 99).

Maslach'a göre, üç boyuttan birisi olan "duygusal tükenme"; bireyin, kendisine duygusal olarak aşırı yüklenildiği ve sahip olduğu duygusal kaynakların tüketildiği biçimindeki algılamalarını ifade etmektedir. Aşırı iş yükü ve işteki kişisel çatışmalar bunun en önemli nedeni olarak ifade edilmektedir.

"Duyarsızlaşma" ise, genellikle duygusal tükenmişliğin giderek artmasına bir yanıt verme niteliğinde, diğer bireylere karşı olumsuz, katı ya da aşırı derecede ilişkisiz tepkiler gösterme şeklinde ifade edilmektedir. Birey, korunmacı bir tavırla, diğer insanlardan farklı ilgilere sahip olduğunu vurgular bir biçimde, onlarla arasına duygusal olarak bir set çeker. Ancak, farklı ilgilere sahip olma duygusunun, insanlardan kaçma ya da uzak durma biçimine dönüşebilecek olması riski mevcuttur. Bu boyut, tükenmenin kişiler arası olan boyutunu ifade etmektedir.

"Azalan kişisel başarı" ise; bireyin, işiyle ilgili becerisine ve verimliliğine dair, sahip olduğu olumlu duyguların giderek körelmesini ve azalmasını ifade etmektedir. Azalan bireysel yeterlilik duygusu, depresyonla 
ve işin gerekleriyle başa çıkmada gerçekten yetersiz kalınmasıyla, yakından ilişkilidir. Bu durum, sosyal bir desteğin olmayışı ve mesleki açıdan gelişim firsatlarının eksikliği ile daha da ivme kazanabilecektir. (Maslach ve Goldberg, 1998, s. 64).

Tükenmişliği, alt boyutlara sahip ve aşamalardan oluşan bir süreç olarak gören Golembiewski, Maslach'ın, tükenmişlik boyutlarına dayandırdığı araştırmasında, bu üç boyutun, düşük ya da yüksek olmasına bağlı olarak, 8 farklı kombinasyon oluşturduğunu ve her bireyin farklı bir kombinasyonu temsil edebileceğini söylemiştir. Ancak Maslach'dan farklı biçimde, bireyin önce bir duyarsızlaşma yaşayacağını, sonrasında kişisel başarısızlık duygusuna sahip olacağını ve en son olarak duygusal bir tükenmişlik yaşayacağını söylemektedir (Golembiewski ve Boudreau, 1991, s. 46).

Tükenmişlik kavramı sıklıkla stres ve depresyon kavramları ile benzer biçimde kullanılmaktadır. Birtakım benzerlikler taşısalar da aralarında farklılıklar söz konusudur. Bu bağlamda stres ve depresyon kavramları, tükenmişlik ile ilişkileri yönünden aşağıdaki gibi verilebilir.

Stres kavramı en basit tanımıla; bir bireyin zihinsel, duygusal ve fiziksel olarak dengede olmaması halini ifade etmektedir. Bireyin, fiziksel ve duygusal tepkiler gösterme imkanına sahip olduğu bir duruma ilişkin algılamalarından kaynaklanmaktadır. Stres, bireyin içinde bulunduğu durumu algılaması ve yorumlamasına bağlı olarak, olumlu ya da olumsuz bir biçimde ortaya çıkabilmektedir. Tükenmişlik kavramı ise, bireyin karşılanmayan ihtiyaç ya da karşılanmayan beklenti algılamaları ile ortaya çıkan bir durumu ifade etmektedir. Bireyin kendisine saygısının azaldığı, psikososyal ve fiziksel belirtilerle kendini gösteren, sürekli biçimde artan bir hayal kırıklığını ifade etmektedir. Zaman içerisinde yavaş yavaş ortaya çıkmaktadır (Gold ve Roth, 1993, s. 44). Tükenmişlik, genellikle uzun bir süre stres oluşturan bir ortamda bulunmanın bir sonucudur. Çeşitli olumsuz stres ortamlarıyla başa çıkma konusunda yaşanan başarısızlık tecrübelerinin en son basamağını ifade etmektedir (Kumar, Hatcher ve Huggard, 2005, s. 407).

Ancak, stres ve stres ortamı, tüm bireyler üzerinde olumsuz bir etki yaratmayabilir ancak tükenmişlik olumsuz bir etkiyi ifade etmektedir. Yani 
tükenmişlik stresin bir sonucu olabilir ancak her stres, tükenmişliğin olumsuz sonuçlarından birisini doğurmayabilir (Fish, 2008, s. 33).

$\mathrm{Bu}$ iki kavram arasındaki temel farklı1ıklar ise aşağıdaki gibi verilebilir (Wright, 2012, s. 132-133).

- Tükenmişlik, ilişkiyi kesme şeklindeki bir savunma biçimi olarak ifade edilebilir. Stres ise duygu yoğunluğunun artması ile ifade edilir.

- Tükenmişlikte duygular körleşir, streste ise çok tepkisel bir hal alır.

- Tükenmişlikte öncelikle duygusal hasar görülürken, streste ise öncelikle fiziksel hasar görülür.

- Tükenmişliğe ilişkin yorgunluk, motivasyon ve girişimde bulunma üzerinde etkili iken, strese bağlı yorgunluk daha çok fiziksel enerji ile ilgilidir.

- Tükenmişlik, moral kaybı meydana getirirken, stres bir yıkım meydana getirir.

- Tükenmişlik, en iyi biçimde, ideallerin ve umutların kaybolması ile anlaşılırken stres ise, en iyi biçimde enerjinin kaybolması ile anlaşılır.

- Tükenmişlik bunalımı, ideallerin kaybolması ve umudun azalması ile üzüntü ve kedere neden olur. Stres bunalımı ise vücudun kendini koruması ve enerjisini muhafaza etme isteğinden kaynaklanır.

- Tükenmişlik, yardımsızlık ve umutsuzluk doğurur, stres ise bir baskı ve hiperaktivite ortaya çıkarır.

Tükenmişlikle benzer olarak kullanılan bir diğer kavram da depresyon kavramıdır. Depresyon kavramı en basit tanımı ile; "Bireyin, yaşamla ilgili aktiviteleri yerine getirmesi için, normal bir ruh halinin çok altında, neşesiz, karamsar, hüzünlü ya da içe kapanık olması" durumudur (Oddenino, 1995, s. 119).

Depresyonu tükenmişlikten ayıran en önemli özellik, tükenmişliğin işteki sosyal çevrenin niteliğinde bir bozulma meydana getirirken, depresyonun yaşamın tüm alanlarını etkiliyor olmasıdır (Kumar vd., 2005, s. 407). 
Depresyon ve tükenmişlik yaşayan bireylerin sahip olduğu davranışsal farklılıkların vurgulandığ 1 bir çalışmada aşağıdaki gibi birtakım farklılıklar tespit edilmiştir (Breninkmeyer, Van Yperen, Buunk, 2001, s. 874).

Tükenmişliği yüksek bireyler, depresyon içerisindeki bireylere kıyasla; a) daha hayat dolu görüntüsüne sahiptirler ve sevdikleri şeyleri daha fazlaca yapma eğilimindedirler, b) daha nadiren kilo kaybı yaşarlar, psikomotor kısıtlamalara sahip olurlar ve intihar konusundaki düşüncelerini anlatırlar c) bir suçluluk duygusuna sahiplerse, bu daha gerçekçi nedenlere dayanan bir suçluluk duygusudur, d) kararsızlıkların ve durgunluklarını, hastalıklarıyla açıklamak yerine tükenmişlikleriyle açıklamaktadırlar, e) genellikle uykuya dalmakta güçlük çekerler.

Tükenmişlik kavramının anlaşılması, aslında stres kaynaklarının ve stresi ortaya çıkaran sürecin de anlaşılmasını gerektirir. Stres konusuyla ilgili yapılan çalışmaları incelendiğinde; etkileşimci modeller, arabulucu/11ımlayıcı modeller ve işlemsel modeller olarak üç başlık altında ele alındığı görülmektedir. Bunlar ise aşağıdaki gibi özetlenebilir (Swain, 2013, s.142):

Etkileşimci modeller: Stresi ortaya çıkaran uyarıcılar ve stresin etkileri üzerinde durmaktadırlar. Bu modellerin çoğu, stres kaynaklarına daha fazla talep duymanın, bireyin daha fazla gerilmesine neden olabileceği şeklinde bir faraziye'ye sahiptirler.

Arabulucu/Ilımlayıcı modeller: $\mathrm{Bu}$ modeller ise, stres kaynakları ve gergin olma durumu, arasındaki ilişkinin ortaya çıkmasında, yaş, cinsiyet ya da sahip olunan bireysel farklılıkların önemli bir açıklama gücüne sahip olduğunu, ifade etmektedirler.

İşlemsel modeller: $\mathrm{Bu}$ modeller stres sürecini, sadece sonuçları açısından değil, aynı zamanda stresin nasıl geliştiğini ve nasıl devam ettiği anlamak için geliştirilmişlerdir. Bu modeller sıklıkla "uyma ya da uyum" kavramını kullanmışlardır. Stres, yeterli bir birey-çevre uyumu olmamasından ortaya çıkmaktadır. (Birey-çevre uyumu teorisi, iş talebi ve iş kontrol modeli, v.b.) 
Maslach, Schaufeli, Leiter tükenmişliğin, birey ve işe bağlı unsurlar arasındaki bir uyumsuzlukla ilişkili olduğunu belirterek, bireyin işle ilgili uyumsuzluk yaşayabileceği 6 alan olduğunu belirtmektedirler. Bunlar ise sırasıyla; iş yükü, kontrol, ödül, kabul görme, adalet ve değerler başlı̆̆ı altında aşağıdaki gibi ifade edilmektedir (Maslach, Schaufeli, Leiter, 2001, s. 414415).

İş yükü: İş yükü uyumsuzluğu, en genel biçimiyle, bireyin sahip olduğu enerjisi ile karşılayabileceğinin çok daha ötesinde bir işe sahip olması şeklinde ifade edilmektedir. Bu uyumsuzluk, bireye nicelik açısından makul olsa bile, becerilerinin ya da eğiliminin uygun olmadığı türde bir iş verilmesinden de kaynaklanabilmektedir.

Kontrol: Kontrol konusundaki uyumsuzluk, bireyin işiyle ilgili ihtiyaç duyduğu kaynaklar üzerinde, yetersiz bir kontrole sahip olması ya da işiyle ilgili karar verme yetkisine sahip olmaması, şeklinde ifade edilmektedir.

Ödül: Bu konudaki uyumsuzluk ise, bireyin yaptığı iş ile elde ettiği sonuçların birbirine uygun olmaması şeklinde ifade edilebilir.

Kabul görme: $\mathrm{Bu}$ uyumsuzluk, iş yerindeki diğer bireylerle olumlu iletişim duygusu kaybolduğunda ortaya çıkmaktadır. Bireyler, paylaşılan duygu ve değerlerle grup içindeki üyeliklerini pekiştirmektedirler.

Adalet: $\mathrm{Bu}$ uyumsuzluk, iş ve birey arasında, işyerinde algılanan bir adalet duygusu olmadığında ortaya çıkmaktadır. İş yükü, ödemeler, değerlemeler ve terfiler gibi birçok konuda adaletsizlik yaşanabilmektedir.

Değerler: Bu uyumsuzluk, bireyin sahip olduğu değerler ile örgütün değerleri arasında bir çatışmanın varlığı ile ortaya çıkmaktadır. Bireyler işleriyle ilgili olarak, etik değerlere ve kendi değerlerine uygun olmayan bir şeyler (örneğin yalan söylemek, aldatmak ya da gerçeklerle ilgili açık sözlü olmamak vb.) yapmaya zorlanabilirler.

Stresi arttıran, tükenmişliğe götürebilecek faktörler; a) yeni başlayanlar için oryantasyon ya da giriş programlarının yokluğu, b) iş yükünün fazlalığı, c) işin rutin bir yapıda oluşu, d) iletişim olanağının kısıtlı oluşu, e) yeterince özerkliğe (otonomiye) sahip olmama, f) kişisel amaç ve değerlerin örgütün 
amaç ve değerleriyle örtüşmemesi, g) uygun olmayan bir liderlik ve yönetsel uygulama biçimi, h) sosyal yalnız bırakma ya da tecrit, şeklinde ifade edilebilir (Schaufeli ve Buunk, 2003, s. 411).

Bireyin çalışma hayatıyla ilişkili muhtemel stres kaynakları 4 başlık altında ifade edilebilir (Borkowski, 2009, s. 240).

-İşle ilgili stres kaynakları (iş yükü, işin temposu, işin türü, işin anlamsızlığı, işteki özerk olma durumu, çalışma saatleri, fiziksel çevre, yalnız çalışma vb),

- Rolle ilgili stres kaynakları (rol çatışması, rol belirsizliği, işteki sorumluluk düzeyi, iş ve aile yaşamı dengesini kurma v.b.),

- Grup üyesi olma ile ilişkili stres kaynakları (astlarla, üstlerle ve çalışma arkadaşlarıyla olan ilişkiler, şiddet ve taciz gibi durumları içeren tehditler, kararlara katılım düzeyi, uygun olmayan yöneticilik ya da liderlik biçimi v.b.)

•Örgütsel yap1 ve örgütsel iklime ilişkin stres kaynakları (Yönetim/liderlik biçimi, iletişim şekilleri, kariyer geliştirme fursatları, iş güvenliği, planlanmamış bir değişim, bir bütün olarak iş doyumu v.b.).

Stres kaynakları ile başa çıkma konusunda, örgüt bireye bir takım sosyal destekler sağlayarak, algılamalarını olumlu yönde değiştirmeye çalışmaktadır. Bu destek 3 başlık altında aşağıdaki gibi ifade edilebilir (Greenhaus vd., 2010, s. 280):

- Stres kaynaklarını azaltmak,

- Stresli durumların birey için ifade ettiği anlamın değiştirilmesine yardım etmek,

- Gerginlik belirtilerini yönetme konusunda yardım etmek.

Stresle başa çıkma konusundaki bireysel çabaları ise; işin sıkıntı veren kısımlarını ortadan kaldırmak; işle ilgili alınan sorumluluğu ve meydan okumayı arttırmaya çalışmak; işe ilişkin görevleri netleştirmeye çalışmak; kariyer fırsatlarını netleştirmeye çalışmak; performansı hakkında geri bildirim alma imkanlarını araştırmak; daha esnek bir çalışma programı istemek; işi başkasına devretmeye çalışmak; örgütü ya da kariyer alanını değiştirmeyi istemek; diğerlerinin tavsiyelerini almaya çalışmak; eğitim ya da deneyim 
yoluyla iş becerilerini geliştirmeyi denemek; çalışma arkadaşları, astları ve denetçiler ile olan çatışmaları çözmeyi denemek; kariyer planlama programlarına katılmak, şeklinde özetlenebilir (Greenhaus vd., 2010, s. 276).

Stres olgusu ve muhtemel bir sonucu olan tükenmişlik, bireysel farklılıklar konusuyla da yakından ilgilidir. Bireysel özelliklere bağlı olarak stres kaynaklarını algılama biçimi ve bu kaynaklarla mücadele yöntemleri de kaçınılmaz biçimde farklılaşmaktadır. En önemli bireysel farklılıkları ise; sorunlarla başa çıkma biçimleri (Problem odaklı başa çıkma, duygusal odaklı başa çıkma, kaçınarak başa çıkma), öz saygı ve öz yeterlilik (içsel ya da dışsal denetim odaklı olmak vb.) ile, kişisel özellikler (içe dönük ya da dışa dönük olma), şeklinde ifade etmek mümkündür (Swain, 2013, s. 144).

Literatürde kariyer ve tükenmişlik konusu arasındaki ilişkiyi inceleyen çeşitli çalışmalar mevcuttur. Ancak kariyer değerlerinin tükenmişlik üzerindeki etkisini inceleyen araştırmalar oldukça sınırlıdır. Bunlardan bazıları ise aşağıdaki gibi verilebilir.

Shanafelt ve arkadaşları, doktorların kariyer uyumu ile tükenmişlik düzeyleri arasındaki ilişkiyi inceledikleri çalışmalarında, doktorların meslekle ilişkili temel görevlerini; hasta bakımı, araştırma, eğitim, uygulama ve hasta bakım ziyareti gerektirmeyen işler şeklinde sınıflandırmışlardır. Doktorlardan, kendileri için anlamlı olan görevleri seçmesi istenmiş ve kendileri için anlamlı olan bu görevlere zamanlarının en az \%20'sini ayıranların tükenmişlik düzeylerinin, zamanlarının \%20'sinden azını ayıranların, yaklaşık yarısı kadar olduğu görülmüştür. Zaman ayırma kriteri bu çalışmada önemli bir öncül olarak bulunmuştur (Shanafelt vd.,2009, s. 994).

Shanafelt ve arkadaşları 6179 Amerikalı doktorla yürütmüş oldukları diğer bir çalışmada, doktorlar ile doktor olmayan vatandaşların, tükenmişlik düzeyleri ile iş ve aile arasında denge kurma ihtiyaçlarını araştırmışlardır. Çalışma sonucunda, doktorların duygusal tükenme (32.1\% ) ve duyarsızlaşma (19.4\%) oranlarının diğer grubun duygusal tükenme $(23.5 \%)$ ve duyarsızlaşma oranlarından (15.0\%) daha yüksek olduğu görülmüştür. Ayrıca benzer biçimde, doktorların çalışma programlarının aile yaşamlarına yeterli 
zaman ayırmayı engellediklerini daha yüksek oranda (40.1\% - $23.1 \%)$ ifade ettikleri görülmüştür (Shanafelt vd., 2012, s. 1381).

Keeton ve arkadaşları ise, doktorlarla yürüttükleri bir araştırmada, tükenmişliğin (kişisel başarı düzeyi ve duygusal esneklik gibi iki önemli unsur ile ifade etmektedirler) kariyer doyumunun bağımsız bir öncülü olduğu bulgusuna ulaşmışlardır. Kişisel başarı düzeyi ve duygusal esneklik kavramlarını açıklama konusunda; "çalışılan saatler ve çalışma programı üzerinde kontrol" ile "toplam haftalık çalışma saati sayısı" kavramlarını iki önemli kavram olarak ifade etmişlerdir. (Keeton, Fenner, Johnson ve Hayward, 2007, s. 953-954) Ayrıca; "çalış1lan saatler ve çalışma programı üzerinde kontrol", "toplam haftalık çalışma saati sayısı", "medeni durum" ve "evde bakım gerektiren çocuklara sahip olmak" gibi faktörlerin, iş ve aile yaşamı dengesi ile kariyer doyumu arasındaki ilişkinin kurulmasındaki aracılık etkisinin, ilişkiyi zayıflattığı görülmüştür (Keeton vd.,2007, s. 953).

\section{YÖNTEM}

\subsection{Araştırmanın Amacı ve Problemi}

$\mathrm{Bu}$ araştırmanın temel amacı, öğretmenlerin kariyer değerlerinin, tükenmişlik düzeyleri üzerindeki etkisini incelemektir. "Kariyer değerleri, tükenmişlik düzeyi üzerinde etkili midir?" sorusu, araştırmanın temel problemidir.

\section{2. Örneklem}

$\mathrm{Bu}$ araştırma için gerekli veriler, Artvin ili, Hopa İlçesinde Millî Eğitim Bakanlığı bünyesinde faaliyet gösteren ilk ve ortaöğretim okullarında görev yapan öğretmenlerden elde edilmiştir.

Hopa'da faaliyet gösteren MEB'e bağl1 13 ilköğretim ve 6 ortaöğretim okulu mevcuttur. Bu okullarda görev yapan öğretmen sayıs1 ise 444'tür. Örneklem, "Kolayda Örnekleme Tekniği" kullanılarak belirlenmiştir. Toplam 187 öğretmene ulaşılmıştır. Katılımcılardan, geri dönen anketlerden 33'ü değerlemeye uygun bulunmamış, 154 anket ise değerlemeye uygun bulunarak analize tabi tutulmuştur.

\section{3. Ölçekler}


İlgili verilerin elde edilmesinde anket formu kullanılmıştır. Araştırmacının bizzat kendisi tarafından, örneklemi oluşturan öğretmenlere konu hakkında gerekli açıklamalar yapılarak, ilgili anket formunu nasıl doldurmaları gerektiği açıklanmıştır. Anket formu üç bölümden oluşmaktadır. Birinci bölümde demografik değişkenlere ilişkin bilgilere yer verilmiştir. İkinci bölümde tükenmişlik ölçeğine ilişkin ifadeler, üçüncü bölümde ise kariyer değerleri ölçeğine bağlı ifadeler yer almaktadır. Araştırmada "kariyer değerleri" bağımsız değişken, "tükenmişlik" ise bağımlı değişken olarak kullanılmıştır.

Öğretmenlerin tükenmişlik düzeylerini ölçmek amacıyla, "Tükenmişlik Ölçeği" olarak, Maslach tarafından geliştirilen ölçeğin uyarlanmış biçimi kullanılmıştır (Maslach ve Jackson, 1981, s. 102-103). Tükenmişliğin 3 boyutuna (Duygusal tükenme, Duyarsızlaşma, azalan kişisel başarı) ilişkin 22 ifadeye yer verilmiştir. Her bir ifade; $1=$ Kesinlikle kat1lıyorum ve 5= Kesinlikle katılmıyorum, arasında derecelere sahip, 5'li Likert ölçeği ile ölçülmüştür.

Öğretmenlerin sahip oldukları kariyer değerlerini öğrenmek amacıyla Schein tarafından geliştirilen "Kariyer Değerleri Ölçeği" kullanılmıştır (Schein, 1990b, s. 4-6). İlgili anket 8 kariyer değerine (Güvenlik, Otonomi/özerklik, Teknik/fonksiyonel beceri, Girişimci yaratıcılık, Genel yönetim becerileri, Hizmet/bir amaca bağlanmışlık, Saf meydan okuma, Yaşam tarzı) ilişkin toplam 40 ifadeyi içermektedir. Her bir ifade; 1= Kesinlikle katıliyorum ve $5=$ Kesinlikle katılmıorum, arasında derecelere sahip 5'li Likert ölçeği ile ölçülmüştür.

\subsection{Analiz Yöntemi}

Anket formu yardımı ile elde edilen veriler SPSS 20 istatistiksel veri analizi paket programı ile analiz edilmiştir. Değişkenler arasındaki ilişkinin incelenmesinde, bağımsız t testi, anova testi, korelasyon ve regresyon analizlerinden yararlanılmıştır.

\section{BULGULAR}


Tablo 1'den de görüldüğü üzere örneklemi oluşturan katılımcıların \%51,9'u kadın, \%48,1'i erkektir. Katılımcıların 37,7'si 26-30 yaş aralığında, $\% 88,3$ 'ü ise lisans mezunudur. Katılımcıların \%61,7'si evli, \%38,3'ü ise bekârdır. Şu an çalıştığı okulda 1-4 yıl arası görev yapan katılımcılar \%75,3 oranıyla en yüksek grubu temsil etmektedirler.

Tablo 1: Demografik değişkenlere ilişkin istatistikler

\begin{tabular}{|c|c|c|c|c|c|c|c|}
\hline \multirow{3}{*}{ Cinsiyet } & & f & $\%$ & \multirow{6}{*}{$\begin{array}{l}\text { Kurumda } \\
\text { geçen süre }\end{array}$} & & f & $\%$ \\
\hline & Kadın & 80 & 51,9 & & 1-4 y1l aras1 & 116 & 75,3 \\
\hline & Erkek & 74 & 48,1 & & $5-8$ yıl aras1 & 20 & 13 \\
\hline \multirow{7}{*}{ Yaş } & $21-25$ & 18 & 11,7 & & $9-12$ y1l aras1 & 8 & 5,2 \\
\hline & $26-30$ & 58 & 37,7 & & 13-16 y1l aras1 & 9 & 5,8 \\
\hline & $31-35$ & 29 & 18,8 & & 17 yıl ve üzeri & 1 & 0,7 \\
\hline & $36-40$ & 22 & 14,3 & \multirow{7}{*}{$\begin{array}{l}\text { Meslekte } \\
\text { geçen süre }\end{array}$} & $1-4$ y1l & 62 & 40,3 \\
\hline & $41-45$ & 17 & 11 & & $5-8$ y1l & 28 & 18,2 \\
\hline & $46-50$ & 7 & 4,5 & & $9-12$ y1l & 18 & 11,7 \\
\hline & $51-55$ & 3 & 2 & & 13-16 y1l & 18 & 11,7 \\
\hline \multirow{5}{*}{$\begin{array}{l}\text { Eğitim } \\
\text { durumu }\end{array}$} & Enstitü & 1 & 0,7 & & $17-20$ y1l & 19 & 12,3 \\
\hline & Önlisans & 4 & 2,6 & & $21-24$ y1l & 4 & 2,6 \\
\hline & Lisans & 136 & 88,3 & & 25 ve üzeri & 5 & 3,2 \\
\hline & Yüksek Lisans & 13 & 8,4 & \multirow{8}{*}{$\begin{array}{l}\text { Kaçınci } \\
\text { görev yeri }\end{array}$} & 1. görev yeri & 45 & 29,2 \\
\hline & Doktora & - & - & & 2. görev yeri & 45 & 29,2 \\
\hline \multirow{3}{*}{$\begin{array}{l}\text { Eğitim } \\
\text { kurumu }\end{array}$} & İlkokul & 31 & 20,1 & & 3. görev yeri & 22 & 14,3 \\
\hline & Ortaokul & 45 & 29,2 & & 4. görev yeri & 25 & 16,2 \\
\hline & Lise & 78 & 50,7 & & 5. görev yeri & 11 & 7,1 \\
\hline \multirow{4}{*}{ Göreviniz } & Müdür & 5 & 3,2 & & 6. görev yeri & 3 & 2 \\
\hline & Müdür Yardımcısı & 10 & 6,5 & & 7. görev yeri & 1 & 0,7 \\
\hline & Sinıf Öğretmeni & 28 & 18,2 & & 8. görev yeri & 2 & 1,3 \\
\hline & Branş Öğretmeni & 111 & 72,1 & \multirow{2}{*}{$\begin{array}{l}\text { Medeni } \\
\text { Durum }\end{array}$} & Evli & 95 & 61,7 \\
\hline & & & & & Bekar & 59 & 38,3 \\
\hline
\end{tabular}

\subsection{Faktör Analizine ve Güvenilirlik Analizine İlişkin Bulgular}

\subsubsection{Tükenmişlik Ölçeği İçin Faktör ve Güvenirlik Analizi}

22 ifadeden oluşan tükenmişlik ölçeği, faktör analizine tabi tutulmuştur. Faktör yükü 0.50'nin altında olan 10 ifade faktör analizinden çıkarılarak tekrar faktör analizine tabi tutulmuştur. Yapılan keşifsel faktör analizi sonucu, bu ölçeğin 3 faktörden oluştuğunu doğrulamaktadır. Faktör yüklerine bakıldığında 0,904 ile 0,691 arasında değiştiği görülmektedir. Ölçeğin 
güvenilirliğini analiz etmek için içsel tutarlılık ölçütü olan Cronbach $\alpha$ katsayısına bakılmıştır. Ölçeğin tümü ve her bir faktör için Cronbach $\alpha$ katsayısı hesaplanmıştır. Tükenmişlik ölçeğinin tümü ve faktörler düzeyinde Cronbach $\alpha>0,60$ olarak bulunmuştur. Duygusal tükenmişlik boyutunun ortalaması $(2,95)$; duyarsılaşma boyutunun ortalaması $(3,48)$; Azalan kişisel başarı boyutunun ortalaması $(3,74)$ olarak bulunmuştur.

\subsubsection{Kariyer Değerleri Ölçeği İçin Faktör ve Güvenilirlik Analizi}

Orjinal olarak 40 ifadeden oluşan kariyer değerleri ölçeği, faktör analizine tabi tutulmuştur. Faktör yükü 0.50 'nin altında olan 2 ifade faktör analizinden çıkarılarak tekrar faktör analizine tabi tutulmuştur. Yapılan keşifsel faktör analizi, bu ölçeğin 8 faktörden oluştuğunu doğrulamaktadır. Faktör yüklerine bakıldığında 0,920 ile 0,626 arasında değiştiği görülmektedir. Ölçeğin güvenilirliğini analiz etmek için içsel tutarlılık ölçütü olan Cronbach $\alpha$ katsayısına bakılmıştır. Ölçeğin tümü ve her bir faktör için Cronbach $\alpha$ katsayısı hesaplanmıştır. Kariyer değerleri ölçeğinin tümü ve faktörler düzeyinde Cronbach $\alpha>0,60$ olarak bulunmuştur. Kariyer değerlerinin alt boyutlarının ortalamaları; Teknik/fonksiyonel beceri $(2,23)$, genel yönetim becerileri $(3,45)$, Otonomi/özerklik $(2,72)$, Güvenlik $(2,35)$, Girişimci yaratıcılık $(1,80)$, Hizmet/bir amaca bağlanmışlık $(2,35)$, Saf meydan okuma $(2,53)$, Yaşam tarzı $(1,94)$ olarak bulunmuştur.

\subsection{Demografik Değişkenlerle İlişskili Bağımsız t Testleri ve Anova Testleri}

\subsubsection{Yaş Değiş̧kenine İlişsin Anova Testi}

Örneklemin yaş değişkenine bağlı olarak, duygusal tükenme, duyarsızlaşma, azalan kişisel başarı, boyutları açısından farklılık gösterip göstermedikleri ANOVA analiziyle incelenmiştir. ANOVA analizi sonuçlarına göre, duygusal tükenme (Fduygusal tükenme $(6,147)=1,84$, $p=0,09)$, duyarsılaşma (Fduyarsızlaşma $(6,147)=0,791, p=0,578)$ ve azalan kişisel başarı boyutlarında (Fazalankişiselbaşarı $(6,147)=0,837, p=0,543$ ) yaş bağımsız değişkenine göre, anlamlı bir farklılık saptanamamıştır.

\subsubsection{Cinsiyet Değişsenine İlişsin Bağımsız t Testi}


Örneklemin cinsiyet değişkenine göre, tükenmişlik boyutları açısından anlamlı bir farklılık gösterip göstermediği bağımsız t testi ile incelenmiş ve duygusal tükenme boyutu ile azalan kişisel başarı boyutunda cinsiyet değişkenine göre anlamlı bir farkl11ık $(\mathrm{p}<0,05)$ olduğu görülmüştür. Test sonucunda kadınların, erkeklere göre daha yüksek oranda duygusal tükenme $(2,72)$ ve daha yüksek oranda azalan kişisel başarı duygusuna $(3,62)$ sahip oldukları görülmüştür. Elde edilen sonuçlar tablo 2'deki gibidir.

Tablo 2: Cinsiyete ilişkin bağımsız t testi analizi

\begin{tabular}{|l|l|l|l|l|l|l|l|}
\hline & Cinsiyet & $\mathbf{n}$ & Ort. & S.s. & t & Df & P (sig.) \\
\hline \multirow{2}{*}{ Duygusal Tükenme } & Kadın & 80 & 2,72 & 1,09 & \multirow{2}{*}{$-2,75$} & \multirow{2}{*}{152} & \multirow{2}{*}{, 007} \\
\cline { 2 - 6 } & Erkek & 74 & 3,20 & 1,08 & & & \\
\hline \multirow{2}{*}{ Duyarsızlaşma } & Kadın & 80 & 3,45 & 1,07 & \multirow{2}{*}{,- 452} & \multirow{2}{*}{152} & \multirow{2}{*}{, 652} \\
\cline { 2 - 5 } & Erkek & 74 & 3,52 & 0,89 & & & \\
\hline \multirow{2}{*}{ Azalan Kişisel Başarı } & Kadın & 80 & 3,62 & 0,58 & \multirow{2}{*}{$-2,62$} & \multirow{2}{*}{152} & \multirow{2}{*}{, 010} \\
\cline { 2 - 5 } & Erkek & 74 & 3,86 & 0,55 & & & \\
\hline
\end{tabular}

\subsubsection{Görev Değişkenine İlişsin Anova Testi}

Örneklemin kurumlarındaki görevlerine bağlı biçimde, duygusal tükenme, duyarsızlaşma, azalan kişisel başarı, boyutları açısından farklılık gösterip göstermedikleri ANOVA analiziyle incelenmiştir. ANOVA analizi sonuçlarına göre, duygusal tükenme (Fduygusal tükenme $(2,151)=0,089$, $p=0,914)$, duyarsızlaşma (Fduyarsızlaşma $(2,151)=0,038, p=0,963)$ ve azalan kişisel başarı boyutlarında (Fazalankişiselbaşarı $(2,151)=3,022, p=0,062$ ) çalışılan eğitim kurumundaki görev bağımsız değişkenine göre, anlamlı bir farklılık saptanamamıştır.

Tablo 3: Değişkenler arasındaki korelasyonlar

\begin{tabular}{|c|c|c|c|c|c|c|c|c|c|c|}
\hline Değişkenler & 1 & 2 & 3 & 4 & 5 & 6 & 7 & 8 & 9 & 10 \\
\hline 1.Teknik ya da fonk. bec. & 1 & & & & & & & & & \\
\hline 2.Genel yönetim bec. &,$- 192^{*}$ & 1 & & & & & & & & \\
\hline 3.Otonomi & ,046 & ,116 & 1 & & & & & & & \\
\hline 4.Güvenlik & 034 & 001 &, 140 & & & & & & & \\
\hline 5.Girişimci yaratıcılık &, $268^{* *}$ &, 067 &, 136 & $5-, 005$ & & & & & & \\
\hline 6.Hizmet &, $327^{* *}$ &,- 037 &, 112 & $2,210^{* * *}$ & ; $402^{* * *}$ & & & & & \\
\hline 7.Saf meydan okuma &, $300^{* *}$ & ,048 &, 153 & $3,206^{*}$ &, 121 &, $411^{* *}$ & & & & \\
\hline 8. Yaşam tarzı &, $215^{* *}$ &,$- 186^{*}$ & $*-, 03$ & 6,054 & ,132 &, $219^{* *}$ & , 068 & & & \\
\hline 9.Duygusal tükenme &,- 130 &,- 082 & 045 &, $163^{*}$ &,- 057 &,- 056 &,- 070 & $0-, 165$ & $5 * 1$ & \\
\hline
\end{tabular}


10.Duyarsızlaşma

028,011, 131,036 -,065, 032, 082 -,074,281**1

11.Azalan kişisel başarı

,036 -,075-,078,105 -,114-,020,001 -,152*,334**,179*1

*. Korelasyon 0,05 düzeyinde anlamlıdır. **. Korelasyon 0,01 düzeyinde anlamlıdır.

\subsection{Tükenmişlik ve Kariyer Değerleri İlişkisine İlişkin Bulgular}

\subsubsection{Korelasyon Analizi}

Değişkenler arasındaki ilişkiyi test etmek amacıyla yapılan korelasyon analizi sonucunda, yaşam tarzı değerinin, hem duygusal tükenmişlik ile hem de azalan kişisel başarı ile 0,05 anlamlılık düzeyinde negatif yönlü bir ilişki içerisinde olduğu görülmüştür. Güvenlik değeri ise sadece duygusal tükenme değişkeni ile 0,05 anlamlılık düzeyinde, pozitif yönde ilişkili olarak bulunmuştur. Korelasyon analizine ilişkin sonuçlar tablo 3'deki gibidir.

\subsubsection{Regresyon Analizi}

Kariyer değerlerinin, tükenmişlik üzerindeki etkilerini görmek amacıyla, basit regresyon analizi yapılmıştır. Regresyon analizi sonucunda anlamlı çıkan bulgular tablo 4' deki gibi verilmektedir. Duygusal tükenme bağımlı değişkeni üzerinde etkili olan kariyer değerlerini belirlemek amacıyla yapılan regresyon analizlerinde, sadece güvenlik değeri $(\mathrm{F}=4,167, \mathrm{p}<.05)$ ve yaşam tarzı değerinin $(F=4,237, p<.05)$ istatistiksel olarak anlamlı olduğu görülmüştür. Güvenlik değeri ve yaşam tarzı değerinin ikisi de duygusal tükenmedeki değişkenliği yaklaşık \% 2 oranında açıklamaktadır. Güvenlik değeri istatistiksel olarak pozitif yönde $(0,163)$ ve anlamlı $(p<.05)$ bir etkileme gücüne sahipken, yaşam tarzı değeri istatistiksel olarak negatif yönde $(-0,165)$ ve anlamlı $(\mathrm{p}<.05)$ bir etkileme gücüne sahiptir.

Tablo 4: Anlamlı çıkan regresyon analizi sonuçları

\begin{tabular}{|c|c|c|c|c|c|c|c|c|c|}
\hline $\begin{array}{l}\text { Bağımsız } \\
\text { Değişken }\end{array}$ & $\begin{array}{l}\text { Bağımlı } \\
\text { Değişken }\end{array}$ & $\mathbf{R 2}$ & $\begin{array}{l}\text { Adj. } \\
\text { R2 }\end{array}$ & $\mathbf{F}$ & B & SE & $\mathbf{t}$ & B & $\mathbf{P}($ sig) \\
\hline Güvenlik & $\begin{array}{l}\text { Duygusal } \\
\text { Tük. }\end{array}$ & ,027 & ,020 & $4,167 *$ & , 195 & ,096 & 2,041 &, $163^{*}$ &, 043 \\
\hline Yaşam tarzı & $\begin{array}{l}\text { Duygusal } \\
\text { Tük. }\end{array}$ & ,027 & ,021 & $4,237 *$ &,- 363 & , 176 & $-2,058$ &,$- 165 *$ &, 041 \\
\hline Yaşam tarzı & $\begin{array}{l}\text { Az. Kiş. } \\
\text { Başarı }\end{array}$ & ,023 & ,017 & $3,595^{*}$ &,- 175 & ,092 & $-1,896$ &,$- 152 *$ & ,049 \\
\hline
\end{tabular}


Duyarsızlaşma bağımlı değişkeni üzerinde etkili olan kariyer değerlerini belirlemek amacıyla yapılan regresyon analizlerinin istatistiksel olarak anlamlı olmadığı görülmüştür.

Azalan kişisel başarı bağımlı değişkeni üzerinde etkili olan kariyer değerlerini belirlemek amacıyla yapılan regresyon analizlerinde, sadece yaşam tarzı değerinin $(\mathrm{F}=3,595, \mathrm{p}<.05)$ istatistiksel olarak anlamlı olduğu görülmüştür. Yaşam tarzı değeri, duygusal tükenmedeki değişkenliği yaklaşık $\% 2$ oranında açıklamaktadır. Yaşam tarzı değeri istatistiksel olarak negatif yönde $(-0,152)$ ve anlamlı $(\mathrm{p}<.05)$ bir etkileme gücüne sahiptir.

\section{SONUÇ VE ÖNERILER}

Mesleki yaşam içerisindeki tüm bireyler birbirlerinden farklılık gösterebilen birtakım değerlere sahiptirler. Sahip oldukları değerlerin meslekleriyle uyumlu olması ise; onların adaptasyon düzeylerini, iş tatminlerini ve karşılaştıkları mesleki zorluklarla mücadele güçlerini de etkilemektedir. Araştırma analizi sonucunda öğretmenlerin sahip oldukları baskın kariyer değerlerinin girişimci yaratıcılık (ort. 1.80) ve yaşam tarzı (ort. 1.94) değerleri olduğu görülmektedir. Girişimci yaratıcılık değeri öğretmenlerin mesleklerinde, yaratıcılıklarını kullanma serbestliğini arzuladıklarını ve böylelikle daha anlamlı sonuçlar elde edebileceklerine ilişkin inançlarının varlığını göstermektedir. Yaşam tarzı değeri ise öğretmenlerin iş yaşamı ve aile yaşamı arasındaki dengeyi sağlama arzusunda olduklarını göstermektedir.

Teknik fonksiyonel beceri değerinin $(2,23)$, güvenlik değerinin $(2,35)$ ve hizmet /bir amaca bağlanmışlık değerinin $(2,35)$ ortalaması yüksek çıkan diğer değerler olduğu görülmektedir. Özellikle çerçevesi belli ve uzmanlığa sahip oldukları bir işi yapıyor olmanın, devlet memurluğu sebebiyle iş güvencesine sahip olmanın ve öğretmenlik mesleğinin her şeyin ötesinde bir ideali temsil etmesinin öğretmenler önemli olduğu değerlemesini yapmak yanlış olmayacaktır.

Öğretmenlerin genel yönetim becerisi değeri $(3,45)$ oldukça düşük olarak bulunmuştur. Bu durum bir okuldaki yöneticilik pozisyonu ile yönetsel görevi olmayan bir öğretmen olarak çalışmanın öğretmenler açısından anlamlı 
bir farklılık içermediği (ast üst ilişkilerinin katı olmaması, fayda ve maliyet analizi sonuçlarının yeterince anlamlı bulunmaması açısından yöneticiliğin tercih edilmemesi, yöneticiliğin iş yaşamı dışında zaman ayırma gerekliliği v.b.) şeklinde değerlendirilebilir.

Yaş ve görev değişkenine bağlı olarak yapılan anova analizlerinin sonucu anlamlı çıkmamıştır. Cinsiyet değişkenine bağlı olarak yapılan t testi sonucunda ise kadın öğretmenlerin duygusal tükenme düzeyleri erkek öğretmenlere göre daha yüksek çıkmıştır. Aşırı iş yükü ve kişisel çatışmalar literatürde duygusal tükenmenin en önemli nedenleri olarak verilmektedir. Kadın öğretmenlerin, cinsiyete has (fizyolojik v.b.) birtakım özellikleri, ev hayatındaki sorumluluklarının (gündelik işler, çocuk bakımı v.b.) erkeklere göre fazla oluşu ilk akla gelen rasyonel nedenlerdir. Ancak bu durum derinlemesine bir analizi gerektirmektedir.

Korelasyon analizi sonucunda güvenlik değeri, duygusal tükenme ile pozitif yönlü bir ilişkiye sahip; yaşam tarzı değeri ise duygusal tükenme ve azalan kişisel başarı boyutları ile negatif yönlü bir ilişkiye sahip olarak bulunmuştur. Güvenlik değeri arttıkça duygusal tükenme düzeyi de artmaktadır. Bu durum, yüksek iş güvenliği arzusuna sahip öğretmenlerin, yaşadıkları mesleki olumsuzluklara karşı daha duyarlı oldukları ve onları rahatsız etmesine rağmen, işlerini kaybetmeme düşüncesiyle, bu duruma daha katlanır oldukları şeklinde değerlendirilebilir.

İş ile aile yaşamı arasında denge kurma olarak da ifade edilen yaşam tarzı değeri arttıkça duygusal tükenme azalmaktadır. Öğretmenlik mesleğinin, iş ile aile yaşamı arasında bir denge sağlamaya imkân tanıyan bir meslek olarak algılanmasının, duygusal tükenmeyi doğuran unsurların (iş yükü, kişisel çatışmalar v.b.) görmezden gelinmesini sağlaması muhtemeldir. Ayrıca mesleğe dair olumsuzluk algılamasının azlığı ya da yokluğunun da bu sonucun ortaya çıkmasına neden olabileceği göz ardı edilmemelidir.

Yaşam tarzı değeri arttıkça, kişisel başarısızlık duygusu giderek azalmaktadır. $\mathrm{Bu}$ durum, çeşitli nedenlerle ilişkilendirilebilir. İş ile aile yaşamı arasındaki denge kurma değerine sahip bireylerin, çeşitli sebeplerle (öğretmenlik mesleğinin içinde kariyer aşamalarının başka mesleklere göre 
daha az oluşu, mesleğin doğasının rutin olması ve gelişime yönelik bir zorlama içermemesi v.b.), mesleğe ilişkin asgari gerekleri yerine getirmenin yeterli olduğu düşüncesini benimsemeleri, ya da mesleki anlamda ilerleme konusunda diğer öğretmenlere kıyasla daha fazla zorluk algılamaları, muhtemel nedenlerin başında gelmektedir.

Bireysel değerlerin, tükenmişlik üzerindeki değişimi açıklama da tek başına yeterli olmadığını söylemek yanlış olmayacaktır. Bireysel değerlerin yanı sıra, birçok içsel ve dışsal etken (örgütsel, yönetsel v.b.) tükenmişlik üzerinde etkileme gücüne sahiptir ve eş anlı olarak bireyler bütün bu değişkenlerin etkisi altındadır. Bu değişkenlerin sayısı ve karşılaşılma sıklığı ise değişkenlik arz etmektedir. Bu yönüyle, yapılan araştırma bir sınırlılık içermektedir ve gerek araştırma bulgularının daha da netleştirilmesi gerekse, diğer faktörlerin etkileme gücünü anlamak açısından daha derin bir analize gereksinim duymaktadır.

\section{KAYNAKÇA}

Borkowski, N. (2009). Organizational Behavior, Theory, and Design in Health Care, Second Edition, London: Jones and Barlett Learning Publishers.

Brenninkmeyer, V., Van Yperen, N. W., ve Buunk, B. P. (2001). Burnout and depression are not identical twins: Is decline of superiority a distinguishing feature?. Personality and Individual Differences, 30 (5), 873-880.

Cherniss, C. (1980). Professional Burnout in Human Service Organizations. New York: Praeger.

Edmonson, S. ve Thompson, D. (2002). Burnout Among Special Educators: A MetaAnalysis. Editör Gordon S. GATES ve Mimi WOLVERTON, Toward Wellness: Prevention, Coping, and Stress (pp.159-177). Information Age Publishing, Inc.

Fish, T. (December 2008). Burnout of Direct Care Staff and Leadership Practices in Residential Treatment Centers for Children and Adolescents. Doctorate Thesis, George Washington University.

Freudenberger, H.J.(1974). Staff Burnout. Journal of Social Issues, 30 (1), 159-165.

Gold, Y. ve Roth, R. A. (1993). Teachers Managing Stress and Preventing Burnout:

The Professional Health Solution. London: Falmer Press. 
Golembiewski, R. T. ve Boudreau, R. (1991). Healtcare professional attend thyself: the epidemiology of burnout in several settings. International Journal of Public Administration, 14 (1), 43-57.

Goodman, J. (2011). Toward a Holistic View: Decision-Making, Postmodern, and Emerging Theories. Editör David CAPUZZI and Mark D. STAUFFER, Career counselling: Foundations, Perspectives, and Applications (pp 81-111), New York: Taylor \& Francis.

Greenhaus, J. H., Callanan, G. A., ve Godshalk, V. M. (2010). Career Management. SAGE Publications.

Hall, D. T. (2002). Careers in and out of organizations, SAGE Publications.

Hallsten, L. (1993). Burning out: a framework. W.B. Schaufeli, C. Maslach and T. Marek (Ed.), Professional Burnout: Recent Developments in Theory and Research içinde (s. 95-112). Washington, DC: Taylor\&Francis.

Keeton, K., Fenner, D. E., Johnson,T. R.B., ve Hayward, R. A., (2007). Predictors of Physician Career Satisfaction, Work-Life Balance, and Burnout. Obstetrics and Gynecology, 109 (4), 949-955.

Kumar, S., Hatcher, S., ve Huggard, P. (2005). Burnout in Psychiatrists: An Etiological Model. The International Journal of Psychiatry in Medicine, 35 (4), 405-416.

Maslach, C., ve Jackson, S. E. (1981). The Measurement of experienced burnout. Journal of Occupational Behaviour, 2 (2), 99-113.

Maslach, C., ve Goldberg, J. (1998). Prevention of Burnout: New Perspectives. Applied \& Preventive Psychology, 7 (1), 63-78.

Maslach, C., Schaufeli, W. B., ve Leiter, M. P. (2001). Job Burnout. Annual Review Psychology, 52 (1), 397-422.

Oddenino, K. (1995). Depression: Our Normal Transitional Emotions, Joy Publications.

Pines, A. M., ve Aronson, E. (1988). Career burnout: Causes and Cures. New York, NY, US: Free Press.

Pines, A. M. (1996). Couple Burnout: Causes and Cures, London: Taylor \& Francis. 
Pines, A. M. (2002). Teacher Burnout: A Psychodynamic existential perspective. Teacher and Teaching: Theory and Practice, 8 (2), 121-140.

Ross, C. M., Beggs B. A.,ve Young, S. J. (2011). Mastering the Job Search Process in Recreation and Leisure Services, Jones and Barlett Publishers.

Schaufeli W. B. ve Buunk, B. P. (2003). Burnout: An Overview of 25 Years of Research and Theorizing. Marc J. SCHABRACQ, Jacques A. M. WINNUBST, Cary L. COOPER (Ed.), The Handbook of Work and Health Psychology içinde (s. 383-429). 2nd Ed, John Wiley \& Sons Ltd.

Schein, E. H. (1990a). Career Stress in Changing Times. Prevention in Human Services, 8 (1), 251-261.

Schein, E. H. (1990b). Career Anchors: Discovering Your Real Values, USA: A Wiley Company, Jossey-Bass/Pfeiffer,

Schein, Edgar (2006). Career Anchors Participants Workbook, Third Edition,.John Wiley \& Sons Inc.

Shanafelt, T. D., West, C. P., Sloan, J. A., Novotny, P. J., Poland, Greg A., Menaker, R., Rummans, T. A., ve Dyrbye, L. N. (2009). Career Fit and Burnout Among Academic Faculty. Archives of Internal Medicine, 169 (10), 990-995.

Shanafelt, T. D., Boone, S., TAN, L., Dyrbye, L. N., Sotile, W., Satele, D., West, C.P., Sloan, J., ve Oreskovich, M. R. (2012). Burnout and Satisfaction With WorkLife Balance Among US Physicians Relative to the General US Population. Archives of Internal Medicine, 172 (18), 1377-1385.

Swain, S. (2013). Applied Psychology: India Specific and Cross-cultural Perspectives. New Vishal Publications.

Wasik, B. H. ve Bryant, D. M. (2001). Home Visiting: Procedures for Helping Families, 2nd ed. SAGE Publications.

Wright, H. N. (2012). Winning over your emotions, Harvest House Publishers. 